\title{
PENGARUH PENGUMUMAN DIVIDEN TERHADAP PERUBAHAN HARGA SAHAM SEBELUM DAN SESUDAH $E X$-DIVIDEN DATE PADA PERUSAHAAN LQ45 YANG TERCATAT DI BURSA EFEK INDONESIA PERIODE 2014-2018
}

\author{
Maisur $^{(1)}$, Nazariah ${ }^{(2)}$ \\ ${ }^{1,2}$ Fakultas Ekonomi Universitas Jabal Ghafur \\ ${ }^{1}$ Maisurmy@gmail.Com, ${ }^{2}$ nazariah@unigha.ac.id
}

\begin{abstract}
ABSTRAK
Penelitian ini bertujuan untuk mengetahui perbedaan harga sebelum dan sesudah ex-dividen date Teknik analisis data yang digunakan dalam penelitian ini adalah dengan melakukan uji beda dua arah rata-rata berpasangan (Paired Sample t-Test) untukmembandingkan rata-rata perubahan, rata-rata closing price portofolio saham pada sebelum dan sesudah ex-dividend date. Teknik pengumpulan data dalam penelitian ini menggunakan teknik dokumentasi.Pada pengambilan sampel menggunakan metode purposive sampling dengan menggunakan kriteria tertentu.Sampel penelitian sebanyak 9 perusahaan LQ 45.Berdasarkan analisis penelitian didapat hasil ujibeda rata- rata abnormal return sebesar 0,152>0,05, sehingga menyatakan bahwa tidak terdapat perbedaan yang signifikan antara harga saham sebelum dan sesudah ex-dividend date pada perusahaan yang terdaftar di Bursa Efek Indonesia periode Januari 2014 sampai Desember 2018
\end{abstract}

Kata Kunci : Saham, Dividen, Ex-dividendate

\section{Pendahuluan}

Tujuan seorang investor yang menginvestasikan dananya dalam perusahaan adalah untuk memperoleh pendapatan yang berupa dividen atau capital gain. Dividen merupakan pendapatan yang diperoleh pada setiap periode selama saham masih dimiliki, sedangkan capital gain adalah pendapatan yang diperoleh karena harga jual saham lebih tinggi dari pada harga belinya.Bagi investor yang bertujuan mendapatkan capital gain juga masih memerlukan Informasi tentang dividen (Brigham \& Ehrhardt, 2011).Informasi merupakan salah satu faktor kunci bagi investor di pasar modal dalam rangka mewujudkan tujuannya yaitu memperoleh return atas investasinya (Byson, 2015). Berdasarkan informasi yang tersedia, investor akan mengambil keputusan kapan akan membeli saham atau mempertahankan saham yang telah dimiliki atau kapan akan melepas saham atau tidak melakukan pembelian sama sekali (Markowitz, 1952). Informasi penting yang dapat mempengaruhi ekspektasi dan keputusan investor dalam berinvestasi adalah pengumuman dividen. Pembayaran dividen merupakan informasi bagi investor bahwa perusahaan memiliki kinerja dan keuangan yang baik.

Secara umum, prosedur pembayaran dividen oleh perusahaan emiten dapat dibagi dalam lima tahap, yaitu tanggal deklarasi (declaration date), tanggal dengan dividen (cumdividen), tanggal tanpa dividen (exdividen), tanggal pencatatan (record date) dan tanggal pembayaran (payment date). Tanggal ex-dividend merupakan salah satu tanggal yang menjadi perhatian oleh investor selain tanggal declaration (tanggal pengumuman dividen). Menganalisis dampak harga saham disekitar tanggal exdividend merupakan isu yang paling penting bagi investor, hal ini disebabkan karena 
pergerakan harga saham disekitar tanggal ex-dividend akan mempengaruhi terhadap keputusan investor untuk berinvestasi karena menyangkut tentang return yang akan diterima oleh investor, yang menghitung variansi return saham pada saat declaration date dan ex dividend date, menemukan adanya kenaikan variansi harga yang signifikan pada ex-dividend date. Hal ini menandakan bahwa investor sangat memperhatikan tanggal ex-dividend dan bereaksi terhadap tanggal ex-dividend tersebut.Semakin banyaknya investor yang berinvestasi maka penulis mencoba untuk melakukan penelitian ini agar dapat mengetahui seberapa besar pengaruh pengumuman dividen terhadap perubahan harga saham sebelum dan sesudah exdividend date. Berdasarkan latar belakang yang ada maka penulis merasa tertarik untuk melakukan penelitian dengan judul "Pengaruh Pengumuman Dividen Terhadap Perubahan Harga Saham Sebelum Dan Sesudah Ex-Dividen Date Pada Perusahaan LQ45 Yang Tercatat Di Bursa Efek Indonesia Periode 2014-2018”.

\section{Kajian pustaka}

\section{Pasar Modal}

Pasar modal atau capital market yaitu sebuah pasar untuk perdagangan dana jangka panjang dalam bentuk obligasi atau saham. Dana yang ditawarkan dalam pasar modal yaitu dana yang berbentuk surat berharga atau sekuritas/efek yang mempunyai jatuh tempo lebih dari satu tahun. Oleh sebab itu pasar modal bisa disebut dengan bursa efek (Akramunnas, 2015:4).Pasar modal (capital market) merupakan tempat diperjual belikannya berbagai instrument keuangan jangka panjang, seperti utang, ekuitas (saham), instrument derivative, dan instrument lainnya (Tjiptono dan Fakhruddin, 2011:1). Pasar modal merupakan sarana pendanaan bagi perusahaan maupun institusi lain (misalnya pemerintah), dan sebagai sarana bagi kegiatan berinvestasi. pasar modal merupakan salah satu sumber alternative pendanaan baik bagi pemerintah maupun swasta. Pemerintah yang membutuhkan dana dapat menerbitkan obligasi atau surat utang dan menjualnya kemasyarakat melalui pasar modal Juliati (2015:2).

\section{Signaling teory (teori Sinyal)}

Signaling teori menyatakan bahwa stock split dianggap perusahaan menyediakan sinyal yang baik kepada publik berkaitan dengan prospek yang baik bagi perusahaan di masa depan, karena perusahaan melakukan stock split adalah perusahaan yang memiliki saham dengan harga tinggi, harga saham tersebutlah yang tinggi sebagai sinyal bahwa perusahaan memilih prospek baik di masa depan, di mana harga saham yang tinggi mencerminkan perusahaan memiliki kinerja yang baik (Hartono, 2014). Menurut Signaling theory, bahwa stock split hanya dilakukan oleh perusahaan yang memiliki kinerja yang baik hal ini disebakan bahwa perusahaan percaya bahwa setelah di pecah harga saham akan naik sesuai dengan kenaikan kinerja perusahaan di masa depan (Fahmi 2012)

\section{Saham}

Saham merupakan kertas tanda bukti penyertaan kepemilikan modal/dana pada suatu perusahaan yang tercantum dengan jelas nilai nominal, nama perusahaan dan diikuti dengan hak dan kewajiban yang jelas kepada setiap pemegangnya (Fahmi, 2012:270). Sedangkan menurut Sudana (2011:87) saham merupakan salah satu alternatif sumber dana jangka panjang bagi suatu perusahaan. Perusahaan yang membutuhkan dana jangka panjang berupa ekuitas, dapat memperolehnya melalui penerbit saham, baik yang dijual melalui private placement maupun melalui intial 
public offering (IPO). Penentuan nilai suatu saham tidak semudah menentukan nilai obligasi, karena pendapatan saham bersifat tidak pasti (Tjiptono dan Fakhruddin (2011:5).

\section{Dividen}

dividen merupakan pembagian sisa laba bersih perusahaan yang didistribusikan kepada pemegang saham atas persetujuan RUPS. Dividen dapat dibentuk tunai (cash dividend) atau saham (stock dividend) (Tjiptono dan Fakhruddin,2011:140). Sedangkan Dividen menurut Raymond (2017:2) merupakan pendapatan yang diperoleh investor sebagai imbal hasil investasi pada saham.dividen dapat dikelompokkan menjadi dua, yaitu: dividen tunai dan dividen saham. Dividen tunai adalah imbal hasil yang diperoleh investor secara tunai, sedangkan dividen saham adalah imbal hasil yang diperoleh investor berupa tambahan jumlah lembar saham yang dimilikinya.

\section{Prosedur Pembagian Dividen}

Adapun prosedur pembagian dividen

yang aktual menurut Tjiptono dan Fakhruddin (2011:142) adalah :

1. Tanggal pengumuman (declaration date), yaitu tanggal pengumuman pembagian dividen yang disampaikan emiten.

2. Cum-Dividend Date, yaitu tanggal terakhir perdagangan saham yang mash mengandung hak untuk mendapatkan dividen (baik tunai maupun saham).

3. Ex-Dividend Date, yaitu tanggal dimana perdagangan saham sudah tidak mengandung hak untuk mendapatkan dividen. Jadi, jika membeli pada tanggal ini atau sesudahnya, saham tersebut sudah tidak lagi memberikan dividen. Sebaliknya, jika seseorang ingin menjual saham dan masih ingin mendapatkan hak dividen, ia harus menjual pada exdividend date atau sesudahnya.
4. Tanggal pencatatan (recording date), yaitu tanggal penentuan para pemegang saham yang berhak mendapatkan dividen.

5. Tanggal pembayaran (dividend payment), yaitu tanggal pembayaran dividen kepada pemegang saham yang berhak.

\section{Metode Penelitian \\ Populasi dan Sampel}

Populasi penelitian ini adalah keseluruhan dari objek yang diteliti.Dalam penelitian ini yang menjadi populasi adalah perusahaan LQ45 yang terdaftar di Bursa Efek Indonesia pada tahun 2014-2018 sebanyak 45 perusahaan.Sampel penelitian ini adalah bagian dari jumlah dan karakteristik yang dimiliki oleh populasi tersebut.Sampel dalam penelitian ini adalah perusahaan yang dipilih sesuai dengan kriteria yang diteliti.Pemilihan sampel dalam penelitian ini menggunakan tehnik purposive sampling yaitu teknik pengambilan sampel dalam pertimbangkan tertentu. Kriteria yang dipertimbangkan adalah sebagai berikut:

1. Sampel yang dipilih adalah perusahaan LQ45 yang terdaftar di BursaEfek Indonesia pada tahun 2014-2018.

2. Perusahaan yang menjadi sampel adalah perusahaan yang selalu membagikan dividen 5 tahun berturut-turut dari tahun 2014-2018.

3. Perusahaan menyajikan data pengumuman pembagian dividen yang lengkap sesuai dengan variabel penelitian.

Penelitian ini menggunakan data dalam bentuk pooled cross sectional. Penelitian dilakukan pada tahun 2014 sampai dengan 2018 dengan sampel sebanyak 9 perusahaan LQ 45, maka secara pooled cross sectional diperoleh sejumlah 9 perusahaan x 5 tahun $=45$ data observasi. Data yang digunakan berasal dari laporan keuangan yang diperoleh dari Bursa Efek Indonesia. 


\section{Teknik Analisis Data}

\section{Uji Beda}

Uji beda dua rata-rata berpasangan (Paired Sample t-Test) untuk membandingkan rata-rata perubahan ratarata closing price portofolio saham pada sebelum dan sesudah ex-dividend date yang diperoleh dari hasil analisasebelumnya dengan nilai dividen per lembar saham yang dibagikan dari seluruh emiten sampel. Uji ini dilakukan untuk menjawab permasalahan tentang apakah besar nilai perubahan harga saham sebanding dengan besarnya nilai dividen yang dibagikan.Dengan tetap menggunakan $\alpha=5 \%$ (Raymond, 2017:11).

\section{Hasil Dan Pembahasan}

\section{Rata-rata Abnormal return}

Hasil perhitungan rata-rata abnormal return secara lengkap selama 10 hari sebelum dan 10 hari sesudah ex-dividend date dapat dilihat pada Tabel 1 rata-rata abnormal return dibawah ini:

Tabel 1. Rata-Rata Abnormal Return

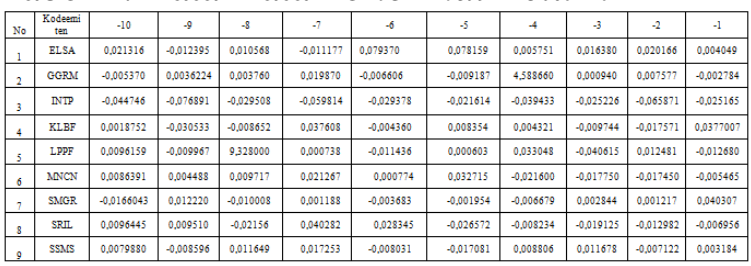

\section{AnalisisDeskriptif}

Hasil analisis deskriptif rata-rata abnormal returnadalah sebagai berikut:

Tabel 2. Statistik Deskriptif Rata-Rata Abnormal Retur

\begin{tabular}{|r|r|r|r|r|r|}
\hline & N & Minimum & Maximum & Mean & Std. Deviation \\
\hline SB_2014 & 10 & -1206 & 746 & -165.30 & 678.573 \\
SB_2015 & 10 & -3371 & 5376 & 918.10 & 2226.655 \\
SB_2016 & 10 & -7317 & 9799 & -736.70 & 4240.146 \\
SB_2017 & 10 & -387 & 2953 & 964.20 & 1069.618 \\
SB_2018 & 10 & -2941 & 1122 & -260.90 & 1148.534 \\
SD_2014 & 10 & -459 & 780 & 125.40 & 442.065 \\
SD_2015 & 10 & -1514 & 3972 & 508.20 & 1553.981 \\
SD_2016 & 10 & -3243 & 721 & -493.60 & 1250.791 \\
SD_2017 & 10 & 147 & 2683 & 1180.00 & 831.638 \\
SD_2018 & 10 & -1036 & 1491 & 276.00 & 846.557 \\
Valid N (listwise) & 10 & & & & \\
\hline
\end{tabular}

Keterangan:

$\mathrm{SB}=$ Sebelum ex-dividenddate

$\mathrm{SD}=$ Sesudah ex-dividenddate

$\mathrm{N}=$ jumlah hari periode penelitian
Berdasarkan tabel4.5diketahui nilai rata-rata abnormal return tertinggi dan terendah pada kelompok sebelum dan sesudah ex-dividen date terdapat pada tahun 2014 yaitu pada kelompok sebelum exdividen date nilai tertinggi sebesar 9799 dan terendah sebesar -7317. Pada kelompok sesudah ex-dividend date nilai terbesar yaitu 3972 dan terkecil sebesar -3243.

\section{Pengujian Hipotesis}

Berikut merupakan hasil pengujian rata-rata abnormal return 10 hari sebelum dan sepuluh hari sesudah ex-dividen date:

Tabel 3

Hasil Uji Beda Rata-rata Abnormal Return

\begin{tabular}{|l|r|}
\hline & $\begin{array}{c}\text { esudah Ex-Dividen } \\
\text { Date - Sebelum Ex- } \\
\text { Dividen Date }\end{array}$ \\
\hline$Z$ & $-1.434^{5}$ \\
Asymp. Sig. (2- & .152 \\
tailed) & .50 \\
\hline
\end{tabular}

Berdasarkan tabel diatas dapat dilihat secara keseluruhan antara 10 hari sebelum dan sepuluh hari sesudah ex-dividen date menghasilkan Sig. (2-tailed) $0,152 \quad>$ 0,05 menandakan hipotesis nol diterima. Hal ini berarti tidak terdapa tperbedaan harga saham sebelum dan sesudah ex-dividen date.

\section{Grafik Rata-rata Abnormal Return}

Gambar 1. Grafik Rata-Rata Abnourmal Return

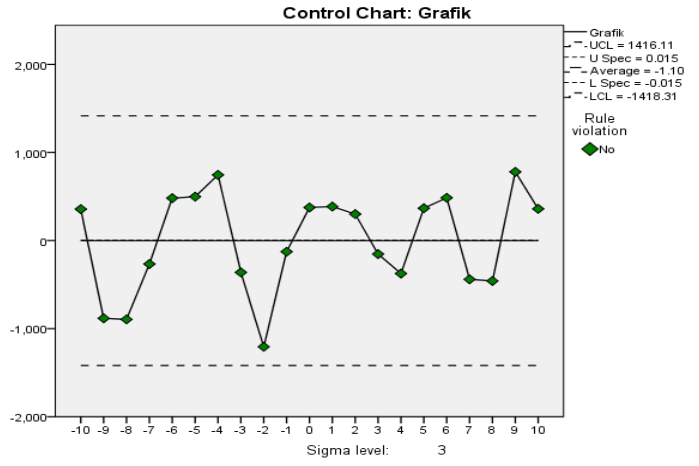


Gambar 1 dapat dilihat pergerakan rata-rata abnormal return seluruh perusahaan diperoleh hasil yang bervariasi. Selama 10 hari periode pengamatan sebelum ex-dividen date, terdapat 5 hari rata-rata abnormal return bernilai positif dan 5 hari bernilai negatif. Pada hari 2 sebelum exdividen date terjadinya penurunan rata-rata abnormal return sebesar -0,01206 dari semula 0,0301 .

Pada penelitian sesudah ex-dividend date terdapat 6hari rata-rata abnormal return bernilai positif dan 4 hari bernilai negative. Terdapat kenaikan rata-rata abnormal return yang signifikan pada hari ke-9setelah exdividend date yaitu sebesar 0,0078.

\section{Pembahasan}

Pada penelitian ini harga saham diukur dengan rata-rata abnormal return.Informasi mengenai ex-dividend date merupakan bagian dari informasi pengumuman dividen yang dipublikasikan oleh suatu emiten yang membagikan dividen. Berdasarkan gambar 1, terdapat kecenderungan rata- rata abnormal return sebelum dan sesudahexdividend date bernilai positif. Munculnya rata-rata abnormal return positif karena beberapa investor memanfaatkan momen exdividend date sebagai even untuk mendapatkan keuntungan yang lebih dari yang telah diestimasi.

Terdapat 6 hari yang mengandung rata-rata abnormal return negative karena investor beranggapan bahwa pembagian dividen bukan merupakan satu-satunya informasi yang akan memberikan keuntungan pada saham yang telah diinvestasikan pada suatu perusahaan, sehingga investor tidak mempertahankan saham yang dimilikinya sampai sebelum exdividend date. Adanya rata-rata abnormal return positif sebanyak 6 hari sesudah exdividend date menunjukkan terdapat beberapa investor yang memanfaatkan pengumuman pembagian dividen di seputar ex-dividend date untuk menjual dengan harga yang lebih tinggi. Adanya 4 hari ratarata abnormal return negative sesudah exdividend date merupakan dampak dari adanya ex-dividend date, dimana jika membeli saham setelah ex-dividend date tidak lagi berhak atas dividen yang akan dibagikan pada saat pembayaran dividen.

Berdasarkan gambar 1 apabila dilihat secara keseluruhan yaitu 10 hari sebelum dan 10 hari sesudahex-dividend date, terdapat rata-rata abnormal return sebelum dan sesudah ex-dividend date mengalami penurunan dan kenaikan yang tidak jauh berbeda. Hal tersebut menandakan bahwa variasi naik turunnya rata-rata abnormal return sebelum ex-dividend date dan variasi naik turunnya rata-rata abnormal return sesudah ex-dividend date tidak memiliki perbedaan yang signifikan.

Menurut information content hypothesis (Sartono, 2012) pembayaran dividen selalu diikuti dengan kenaikan harga saham, harga saham yang tinggi dapat dilihat dari tanggal pengumuman sampai pada tanggal sebelum ex- dividend date. Kemudian, PSAK No 49 tentang Akuntansi Reksadana mengungkapkan bahwa harga saham akan cenderung turun pada waktu exdividend date karena saham sudah tidak mengandung hak dividen. Oleh sebab itu pembagian hak tidak dicatat pada cum dividend date.Adanya teori information content hypothesis (Sartono, 2012) dan PSAK no 49 tentang Akuntansi Reksadana memunculkan pemikiran bahwa pembagian dividen akan membuat harga saham dipasar mengalami kenaikan harga saham sebelum ex-dividend data, penurunan harga saham pada saat dan sesudah ex-dividend date.

Namun, dari hasil pengujian statistik keseluruhan rata-rata abnormal return untuk melihat perbedaan harga saham yang telah dilakukan terhadap 45 sampel perusahaan yang mengumumkan ex-dividend date yang terdaftar dalam Bursa Efek Indonesia, 
memperoleh hasil yang didapat seperti pada Tabel 3 adalah nilai sig (2-tailed) sebesar 0,152. Nilai sig (2-tailed) sebesar 0.152 lebih besar dari pada nilai level of significant 0,05 yang berarti tidak terdapat perbedaan harga yang signifikan sebelum dan sesudah ex-dividend date.

Hasil yang menyatakan bahwa tidak terdapat perbedaan harga saham sebelum dan sesudah ex-dividend date, sesuai teori tidak relevan yang dikemukakan Sartono (2012).Teori ini menganggap bahwa kebijakan dividen tidak membawa dampak apapun bagi perusahaan, baik harga saham maupun biaya modal. Keputusan apakah laba akan dibayar kan dalam bentuk dividen atau akan ditahan tidak akan mempengaruhi nilai perusahaan, sehingga apabila terdapat perusahaan yang membagikan dividen maupun perusahaan yang tidak membagikan dividen tidak akan direaksioleh investor terutama pada sekitarex-dividend date, karena menurut teori tidak relevan dividen tidak akan mempengaruhi reaksi investor dan diduga bahwa reaksi investor dipengaruhi factor selain pembagian dividen.

Hasil penelitian ini mendukung penelitian yang dilakukan oleh Fahmi (2012) yang menyatakan bahwa tidak terdapat perbedaan yang signifikan terhadap rata-rata abnormal return sebelum dan sesudahex- dividend date, karena pembayaran dividen tidak akan mempengaruhi kemakmuran pemegang saham.

\section{Kesimpulan}

Berdasarkan hasil analisis dan pembahasan didapat hasil ujibeda rata- rata abnormal return sebesar 0,152>0,05, sehingga menyatakan bahwa tidak terdapat perbedaan yang signifikan antara harga saham sebelum dan sesudah ex-dividend date pada perusahaan yang terdaftar di
Bursa Efek Indonesia periode Januari 2014 sampai Desember 2018.

Pengumuman pembagian dividen tidak mengakibatkan perbedaan yang signifikan terhadap harga saham yang diukur dengan rata-rata abnormal return sebelum dan sesudah ex-dividend date artinya investor tidak tertarik dengan adanya pembagian dividen. Investor beranggapan bahwa pembagian dividen bukan merupakan satusatunya informasi yang akan memberikan keuntungan pada saham yang telah diinvestasikan pada suatu perusahaan, sehingga investor tidak mempertahankan saham yang dimilikinya sampai sebelum exdividend date.

\section{Saran}

Berdasarkan keterbatasan yang ada, maka bagi penelitian yang akan datang disarankan untuk:

1) Diharapkan dapat melakukan pengelompokan proporsi kepemilikan perusahaan dan dapat mengelompokkan berdasarkan sektor, sehingga dapat melihat sectormana yang paling dominan.

2) Diharapkan menggunakan sampel perusahaan yang berturut-turut membagikan dividen, sehingga sampel dapat dibedakan menjadi dividen turun maupun dividen tetap.

\section{Daftar Pustaka}

Agus Sartono. 2012. Manajemen Keuangan Teori dan Aplikasi. Edisi4. BPFE.Yogyakarta.

Akramunas. 2015. "Pengaruh Pengumuman Dividen Terhadap Harga Saham PT.Vale Indonesia tbk di Bursa Efek

Indonesia (BEI)". Jurnal Fakultas Ekonomi dan Bisnis Islam UIN Alauddin Makkassar. Vol.1 No. 2 
Brigham, E.F., Ehrhardt, Michael C., (2011), Financial Management Theory and Practice (edisi ke 13), Cengage Learning, USA South Western.

Byson B. Majanga (2015) The Dividend Effect on Stock Price-An Empirical Analysis of Malawi Listed Companies. Journal Accounting and Finance Research. Vol 4 No 3

Fahmi, Irham. 2012. Pengantar Manajemen Keuangan. Bandung : Alfabeta.

Harmono. 2011. Manajemen Keuangan Berbasis Balanced Scorecard Pendekatan Teori, Kasus, dan Riset Bisnis, Cetakan Kedua. Jakarta : PT. Bumi Aksara

Hartono, Jogiyanto. 2014. Teori Portofolio dan Analisis Investasi. Edisi Sembilan. BPFE, Yokyakarta.

Hidayati, Alvin Mulya. 2014. "Analisis Harga Saham Dan Rata-Rata Abnormal Return Sebelum Dan Sesudah Ex-Dividend Date (Studi Pada Emiten Indeks Kompas100)". Jurnal Ekonomi dan Bisnis. Vol. 13 No.1

Juliati, Yenni Samri Nasution. 2015. "Peranan Pasar Modal Dalam Perekonomian Negara". Jurnal Ekonomi dan Bisnis.Vol. 2 No. 1

Raymond. 2017.” Pengaruh Pengumuman Pembagian Dividen Terhadap Harga Saham Sebelum Dan Sesudah Ex Dividend Date Pada Kelompok Industri Manufaktur \&
Jasa Yang Terdaftar Di BEI". Jurnal Akuntansi.Vol. 5 No.2

Sudana.2011. Manajemen Keuanagan Perusahaan Teori \& Praktik. Jakarta : Erlangga

Tjiptono, Darmadji, \& Fakhruddin.2011. Pasar Modal Di Indonesia. Edisi. Ketiga. Jakarta : Salemba Empat. 